\title{
OSTATNI AKT POLITYCZNEJ WSPÓŁPRACY SŁOWIAN NA BAŁKANACH. SOJUSZ BAŁKAŃSKI 1912 ROKU
}

\author{
Jarosław Rubacha
}

(1) http://orcid.org/0000-0002-2293-247X

Uniwersytet Warmińsko-Mazurski w Olsztynie (Polska)

\section{ABSTRACT \\ LAST ACT OF POLITICAL COOPERATION OF SLAVS ON THE BALKANS. BALKAN ALLIANCE, 1912}

The deep changes on the political map of the Balkan Peninsula, which followed after the Congress of Berlin in 1878, opened a new chapter in the relations between the nations inhabiting this region. Although the arbitrary decisions taken by the great powers increased the rivalry between the Balkan Slavs, the fact that most of the European territory of Turkey had been left within its borders undoubtedly encouraged the Bulgarians, Serbs, Montenegrins and Greeks to take measures aimed at mutual rapprochement and finding the ultimate solution to the so-called Turkish issue. Despite numerous problems, these ideas were implemented in 1912, through creating the Balkan League, but as it soon turned out, it was the last act of political cooperation between the Slav nations in Southeastern Europe.

Keywords: Balkan Alliance, Balkan states 1912-1913, Russia.

Słowa kluczowe: sojusz bałkański, państwa bałkańskie 1912-1913, Rosja.

W zgodnej opinii badaczy zajmujących się dziejami Europy wiek XIX, a zwłaszcza jego druga połowa, stanowił przełomowy okres w dziejach Starego Kontynentu. Krystalizowanie się i upowszechnianie nowych nurtów ideologicznych będących spuścizną Wielkiej Rewolucji Francuskiej i filozofii romantyzmu w połączeniu z szybkim rozwojem techniki i produkcji fabrycznej wpływały znacząco na wszystkie obszary życia społecznego, a głębokie zmiany objęły także szeroko rozumianą politykę, zarówno w jej wewnętrznym, jak i zewnętrznym wymiarze. $Z$ jednej strony okres ten przyniósł bowiem wyodrębnienie się wielkich mocarstw, które - korzystając z przewagi ekonomicznej i militarnej - rozpoczęły budowę swoich kolonialnych 
imperiów, zacięcie rywalizując miedzy sobą zarówno o terytoria zamorskie, jak i o strefy politycznego i gospodarczego wpływu, a jednocześnie gros swojej uwagi poświęcając zabezpieczaniu istniejącego w Europie status quo i blokowaniu wszelkich prób jego zmiany. Z drugiej strony cieszące się coraz większą popularnością nurty wolnościowe mobilizowały ówczesne bezpaństwowe narody do podejmowania działań na rzecz stworzenia lub reaktywacji państwowości, co nieuchronnie prowadzić musiało do zmiany istniejącego porządku i ułożenia nowego ładu w Europie lub przynajmniej w poszczególnych jej częściach. Nałożenie się tych dwóch przeciwstawnych koncepcji skutecznie dynamizowało sytuację polityczną na Starym Kontynencie, a terenem, gdzie szczególnie było to widoczne, był Półwysep Bałkański ${ }^{1}$. Przyczyną takiego stanu rzeczy był fakt, że potężne terytorialnie, wielonarodowe Imperium Osmańskie od dłuższego czasu pogrążało się w wewnętrznym kryzysie, a z jego słabości starały się skorzystać zarówno mocarstwa europejskie, jak i dążące do realizacji swych celów narody zamieszkujące jego terytorium. Przełomowym momentem w tej konfrontacji stała się wojna rosyjsko-turecka w latach 1877-1878 i kończący ją traktat pokojowy z San Stefano, a zwłaszcza traktat berliński, którego postanowienia przez kilka dziesięcioleci determinowały wydarzenia rozgrywające się w Europie Południowo-Wschodniej.

Poprzez klauzule tego dokumentu wielkie mocarstwa zabezpieczyły wprawdzie swoje partykularne interesy, ratując Turcję przed utratą znacznej części jej bałkańskich posiadłości, ale jednocześnie brutalnie ograniczyły nadzieje państw bałkańskich na realizację narodowych celów. Szczególnie dotkliwie odczuli to Bułgarzy, Serbowie i Czarnogórcy, a poczucie doświadczonej niesprawiedliwości było tym większe, że poprzez narzucone w traktacie berlińskim warunki mocarstwa zyskały nie tylko możliwość blokowania prób nawiązania bliższej współpracy, ale także skutecznego podburzania ich przeciw sobie. Mimo tych niesprzyjających okoliczności państwa bałkańskie podejmowały działania na rzecz ujednolicenia stanowisk w różnych obszarach, a efektem prowadzonych w ostatnich latach XIX i na początku $\mathrm{XX}$ wieku dyskusji było kilka realnych w swych zarysach planów współdziałania w kwestii zabezpieczenia własnych interesów w Europie Południowo-Wschodniej. Koncepcje te nie wchodziły jednak w fazę realizacji, a przyczyną takiego stanu rzeczy były zarówno oficjalne i zakulisowe działania Turcji i wielkich mocarstw, jak i przybierająca na sile rywalizacja i rosnący wzajemny brak zaufania odnośnie do szczerości składanych przez potencjalnych partnerów deklaracji. Przełomowym momentem stał się dopiero rok 1908, a zachodzące wówczas - powiązane z sobą i nakładające się na siebie - procesy stworzyły sprzyjające warunki współpracy między państwami bałkańskimi.

Czynnikiem, który znacząco przyspieszył działania w tym obszarze, była rozpoczęta przez wielkie mocarstwa na przełomie 1903 i 1904 roku akcja reformatorska w Macedonii, będąca reakcją na szalejący w tej prowincji terror po stłumieniu przez Turków powstania ilindensko-preobrażenskiego. Działania te, jakkolwiek przybrały relatywnie szeroki wymiar, nie wpłynęły znacząco na poprawę położenia

1 M. Tanty, Konflikty bałkańskie w latach 1878-1918, Warszawa 1968, s. 3. 
chrześcijańskiej ludności na ziemiach macedońskich ${ }^{2}$, co spowodowane było przede wszystkim wrogim nastawieniem Wysokiej Porty. W Konstantynopolu akcję tę odbierano bowiem jako mieszanie się mocarstw w wewnętrzne sprawy Turcji i starano się ją za wszelką cenę zablokować. Nie ulega jednak wątpliwości, że wzrost nacisków na rząd turecki przyspieszył wybuch rewolucji młodotureckiej w 1908 roku$^{3}$, a wysuwane $\mathrm{w}$ jej trakcie hasła przebudowy państwa opartej na konstytucyjnym prawie równości wszystkich obywateli skłoniło „koncert europejski” do wycofania się z akcji reformatorskiej w Macedonii. Tymczasem akcja ta równie krytycznie oceniana była w państwach bałkańskich, które nie zostały dopuszczone do współudziału w jej prowadzeniu i postrzegały ją jako ingerencję w wewnętrzne sprawy bałkańskie ${ }^{4}$. Jednocześnie bardzo szybko okazało się, że propagowane przez młodoturków liberalne hasła są wyłącznie fasadą, za którą zamierzają przeprowadzić daleko posuniętą osmanizację kraju, gwarantując pełnię praw wyłącznie ludności tureckiej i spychając pozostałe grupy na margines życia społecznego ${ }^{5}$. Decyzje te przyniosły nie tylko wzrost ucisku religijnego i fiskalnego w Macedonii, co spotkało się z ostrą krytyką sąsiednich państw bałkańskich, ale także ograniczały swobody uprzywilejowanych do tej pory Albańczyków, motywując ich do stawienia zbrojnego oporu.

Przejęcie władzy w Turcji przez środowiska zapowiadające odnowienie potęgi osmańskiej było także reakcją na ogłoszoną w styczniu 1908 roku deklarację Austro-Węgier, że planują one anektować okupowaną od 1878 roku Bośnię i Hercegowinę. Stąd też podejmowane przez młodoturków działania, które z zadowoleniem przyjmowane były przez mieszkańców tej prowincji ${ }^{6}$, odbierane były w Wiedniu jako próba zmiany ustalonego podczas kongresu berlińskiego geopolitycznego ładu w tej części Europy i zagrożenie austro-węgierskiego stanu posiadania na Półwyspie Bałkańskim. Potencjalna możliwość utraty kontroli nad Bośnią i Hercegowiną skłoniły gabinet wiedeński do podjęcia decyzji o inkorporowaniu tej prowincji w granice monarchii habsburskiej w październiku 1908 roku ${ }^{7}$ Krok Austro-Węgier, niezależnie od zamiarów decydentów, wywołał poważny kryzys, który omal nie zakończył się wybuchem

2 A. Miecznik, Macedonja i Macedończycy, Warszawa 1904, s. 89-90; I.F. Fraser, Pictures from the Balkan, London 1906, s. 211-212.

${ }^{3}$ H. Batowski, Państwa batkańskie 1800-1923. Zarys historii dyplomatycznej i rozwoju terytorialnego, Kraków 1938, s. 158; R. Poincaré, Geneza wojny światowej. Sześć odczytów w Paryżu w 1921 r., Kraków 1921, s. 57; T. Wituch, Tureckie przemiany. Dzieje Turcji 1878-1913, Warszawa 1980, s. 100-119.

4 М. Семов, Победителят проси мир. Балканските войни 1912-1913, София 1995, s. 44-45.

5 Die große Politik der europäischen Kabinette, 1871-1914. Sammlung der diplomatischen Akten des Auswärtigen Amtes, hrsg. J. Lepsius, A. Mendelssohn-Bartholdy, F. Thimme (dalej: DGP), Bd. 33, Berlin 1926, nr 12036, 12037, 12043; Österreich-Ungarns Aussenpolitik von bosnischen Krise 1908 bis zum Kriegsausbruch 1914. Diplomatische Aktenstücke des Österreich-Ungarischen Ministeriums des Äusseren, ausg. L. Bittner, A.F. Pribram, H. Srbik, H. Übersberger (dalej: ÖUA), Bd. 2, WienLeipzig 1930, nr 1647; T. Wituch, op. cit., s. 135, Н. Станев, История на нова България 1878-1928, София 1929, s. 199; O. Bickel, Russland und die Entstehung des Balkanbundes 1912. Ein Beitrag zur Vorgrschichte des Weltkrieges. Dargestellt vorwiegend auf Grund des amtlichen Aktenmaterials, Königsberg-Berlin 1933, s. 82-83.

6 DGP, Bd. 24, nr 8978.

7 ÖUA, Bd. 2, nr 1182. 
konfliktu w ogólnoeuropejskiej skali, ale - co istotniejsze - uświadomił państwom bałkańskim fakt, że klauzule traktatu berlińskiego nie są niezmienne, skoro w znaczący sposób naruszył je jeden z sygnatariuszy, a zarazem gwarant istniejącego status quo.

Jednocześnie na Bałkanach sytuacja ulegała dalszej komplikacji. Rozwijający się w Albanii ruch powstańczy, którego mimo ponawianych kilkakrotnie prób Turcy nie byli w stanie rozbić ${ }^{8}$, szybko przybrał szerszy polityczny wymiar, wyrażający się żądaniem nadania autonomii wszystkim czterem uznawanym za albańskie wilajetom. Taki stan rzeczy z niepokojem obserwowano w państwach bałkańskich, ponieważ idea ta cieszyła się poparciem części mocarstw, a znaczną część wskazanego przez Albańczyków terytorium stanowiły, newralgiczne z ich punktu widzenia, ziemie macedońskie9. Wydarzenia te motywowały polityków bułgarskich i serbskich, ale także czarnogórskich i greckich zarówno do rewizji poglądów w kwestii wzajemnych stosunków, jak i podjęcia działań na rzecz nawiązania współpracy. Początkowo proces ten przebiegał jednak wolno, a mimo zbieżności celów potencjalni koalicjanci nie wykazywali zainteresowania zainicjowaniem rozmów. Przełomowym momentem okazał się dopiero wybuch wojny włosko-tureckiej we wrześniu 1911 roku, która w całej rozciągłości potwierdziła słabość tureckiej armii ${ }^{10}$ oraz zaangażowanie się w mediacje dyplomacji rosyjskiej.

Podjęcie się przez Rosję roli pośrednika w pertraktacjach państw bałkańskich podyktowany był przede wszystkim zwrotem, który dokonał się w rosyjskiej polityce zagranicznej po klęsce w wojnie z Japonią w 1905 roku. Powracając do aktywnych działań w wymiarze europejskim, Rosjanie przystąpili wówczas do poszerzania i umacniania swojej strefy wpływów w okolicach cieśnin czarnomorskich, zwracając przy tym szczególną uwagę na Półwysep Bałkański ${ }^{11}$. Prace te prowadzone były początkowo bardzo ostrożnie, a naczelnym ich celem było zabezpieczenie stabilnej sytuacji w tym rejonie poprzez budowę bloku państw z Turcją na czele, który kontrolowany przez Rosję mógłby stanowić nie tylko tamę dla penetracji mocarstw centralnych w Europie Południowo-Wschodniej, ale także wygodne narzędzie dla polityki ententy we wschodniej części basenu Morza Śródziemnego. Podejmowane przez ambasadora w Konstantynopolu Nikołaja Czarykowa w 1909 i 1910 roku wysiłki na rzecz realizacji tego planu nie zakończyły się jednak sukcesem ${ }^{12}$, co skłoniło rosyjskie Ministerstwo Spraw Zagranicznych do zwrócenia większej uwagi na najsilniejsze na Bałkanach państwa - Serbię i Bułgarię ${ }^{13}$, które w tym czasie nieśmiało deklarowały chęć ujednolicenia stanowisk odnośnie sytuacji w Macedonii ${ }^{14}$. Jednocześnie dyplomacja rosyjska powróciła do lansowania haseł panslawistycznych,

8 H. Batowski, Państwa..., s. 176; Н. Станев, op. cit., s. 196-197.

M. Tanty, Rosja wobec wojen batkańskich 1912-1913, Warszawa 1970, s. 54.

10 A. Krzyżanowski, Wojna bałkańska w roku 1912/13, Kraków 1913, s. 68.

11 O. Bickel, op. cit., s. 73-74.

12 DGP, Bd. 27, T. 1, nr 9748, 9751; ÖUA, Bd.2, nr 2039, 2042, 2043; H. Batowski, Państwa..., s. 178 .

13 B. von Siebert, Diplomatische Aktenstücke zur Geschichte der Ententepolitik der Vorkriegsjahre, Berlin 1921, s. 137.

14 Ibidem, s. 138-140. 
a w stosowanej retoryce wielokrotnie podkreślała, że Rosja jest jedynym „obrońcą słowiańskich interesów na Bałkanach" i gwarantem popularnej wówczas w Europie Południowo-Wschodniej idei „Bałkany dla narodów bałkańskich”"15. Jakkolwiek deklaracje te przyjmowane były z dużą rezerwą, rosyjscy posłowie w Belgradzie Nikołaj Hartwig i w Sofii Aleksander Niekludow ${ }^{16}$ już wiosną 1910 roku otrzymali polecenie silniejszego zaangażowania się w działania na rzecz serbsko-bułgarskiego zbliżenia. Prowadzone przez kilka miesięcy prace nie przyniosły jednak spodziewanych rezultatów, a prowadzący je dyplomaci donosili do Petersburga, że liczne rozmowy, jakie odbyli na ten temat, „nie doprowadziły do jakichkolwiek konkretnych wyników i można z pewnością stwierdzić, że przy obecnym stanie rzeczy także teraz jakikolwiek sukces w tej kwestii nie może zostać osiągnięty"17. Przyczyną takiego stanu rzeczy było konsekwentne unikanie przez obie strony jasnych deklaracji w kwestii macedońskiej oraz ogólnie niechętny stosunek do szukania dróg porozumienia, prezentowany przez bułgarskie kręgi polityczne z carem Ferdynandem i premierem Aleksandyrem Malinowem na czele.

Sytuacja uległa zmianie dopiero wiosną 1911 roku po objęciu sterów rządu w Bułgarii przez jednego z liderów obozu rusofilskiego Iwana E. Geszowa. Już w połowie kwietnia tego roku na polecenie gabinetu z ówczesnym serbskim ministrem spraw zagranicznych Milovanem Milovanowiciem spotkał się bułgarski poseł w Belgradzie Andrej Toszew ${ }^{18}$. W trakcie dyskusji politycy wyrazili wolę nawiązania współpracy, której celem byłoby poprawienie położenia ludności chrześcijańskiej w Macedonii oraz przeciwdziałanie idei autonomii ziem albańskich ${ }^{19}$. Zadeklarowana przez stronę serbską gotowość do podjęcia negocjacji została pozytywnie przyjęta przez rząd bułgarski, który we wrześniu 1911 roku wysłał do Belgradu z tajną misją posła w Rzymie Dimityra Rizowa ${ }^{20}$. Podczas rozmów z premierem M. Milovanoviciem ${ }^{21}$, Nikolą Pašiciem i Ljubomirem Stojanoviciem strony potwierdziły zainteresowanie zainicjowaniem konsultacji na temat sojuszniczego porozumienia oraz określiły główne obszary, których dotyczyć powinny dalsze dyskusje, a za naczelne zadanie uznano zgodne współdziałanie na rzecz poprawy bytu ludności chrześcijańskiej w europejskich posiadłościach Wysokiej Porty. W opinii serbskich polityków rozwiązanie tej kwestii mogłoby zostać osiągnięte poprzez nadanie im szerokiej autonomii w ramach państwa tureckiego. Gdyby jednak okazało się to niemożliwe, Serbowie sugerowali podjęcie działań zbrojnych przeciw Turcji i podział położonego na Bałkanach terytorium tureckiego między oba państwa, przy czym za bezsprzecznie bułgarską część

15 G. Roloff, Die Entstehung des Balkanbundes von 1912, Giessen 1922, s. 10.

16 B. von Siebert, op. cit., s. 151.

17 Ibidem, s. 146-148.

18 А. Тошев, Балканските войни, т. 1, София 1929, s. 307; И.Е. Гешов, Балканский союз. Воспоминания и документы, Петроград 1915, s. 8-11; H. Batowski, Podstawy sojuszu bałkańskiego 1912. Studia z historii dyplomatycznej 1806-1912, Kraków 1939, s. 108.

19 А. Тошев, ор. cit., s. 308.

20 И.Е. Гешов, оp. cit., s. 13; М. Семов, оp. cit., s. 45; Е. Стателова, Р. Попов, В. Танкова, История на българската дипломация 1879-1913 г., София 1994, s. 425-426.

21 Milan Milovanović objął urząd premiera 25.11.1911. 
uznali Trację, a za serbską Kosowo. Nie podjęli oni jednak dyskusji na temat przebiegu przyszłej wspólnej granicy w Macedonii. Dlatego też Rizow zaproponował, aby tę część zdobyczy wojennych uznać za tak zwaną strefę sporną, o której podziale zadecydować miała Rosja ${ }^{22}$. Stanowisko to strona serbska zobowiązała się rozważyć, a jednocześnie poprosiła o przygotowanie projektu porozumienia, który stałby się podstawą dalszych konsultacji.

W tym czasie doszło jednak do wybuchu wojny włosko-tureckiej, która diametralnie zmieniała stosunki geopolityczne w basenie Morza Śródziemnego, co motywowało zarówno Serbów, jak i Bułgarów do przeprowadzenia jak najszybszych konsultacji na temat nowej sytuacji. Zdawano sobie sprawę, że powinny one mieć zakulisowy charakter, aby w ich przebieg nie mogły ingerować niepożądane czynniki. Dlatego uzgodniono, że rozmowy odbędą się potajemnie podczas powrotu przebywającego wówczas we Francji Geszowa do $\mathrm{kraju}^{23}$. Po drodze bułgarski premier zatrzymał się w Wiedniu, gdzie spotkał się z przybyłym tam 5 października 1911 roku Rizowem, który zaprezentował mu wstępny projekt traktatu sojuszniczego ${ }^{24}$ oraz zreferował przebieg konsultacji w Belgradzie. Mając pełne przeświadczenie, że zawarcie bułgarsko-serbskiego układu jest możliwe, Geszow spotkał się także $\mathrm{z}$ ambasadorem rosyjskim w monarchii habsburskiej Nikołajem Girsem ${ }^{25}$. W trakcie rozmowy poinformował go o planach rozpoczęcia konsultacji w tej kwestii, a jednocześnie poprosił o rosyjskie gwarancje dla takiego aliansu. Wbrew oczekiwaniom Girs nie był jednak zorientowany w szczegółach działań rosyjskiej dyplomacji na Bałkanach. Nie tylko więc odmówił udzielenia gwarancji, ale także wezwał bułgarskiego premiera do zachowania spokoju i powstrzymania się od wszelkich inicjatyw politycznych ${ }^{26}$. Mimo to Geszow skonsultował się z przebywającym w Austrii carem Ferdynandem ${ }^{27}$, a po uzyskaniu jego aprobaty, udał się do Belgradu, gdzie 11 października 1911 roku, w ścisłej tajemnicy, przeprowadził trzygodzinne rozmowy z Milovanoviciem ${ }^{28}$. W trakcie spotkania obaj politycy zaprezentowali przygotowane uprzednio projekty porozumienia. Ponieważ treść dokumentów opracowana została na podstawie przeprowadzonych kilka tygodni wcześniej konsultacji, ich główne założenia się nie różniły. Oba zakładały, że przyszły układ sojuszniczy będzie miał charakter zaczepno-obronny i skierowany zostanie zarówno przeciw jakimkolwiek próbom zmiany istniejącego na Półwyspie Bałkańskim status quo, jak i przeciw Turcji, a zawarty zostanie za wiedzą Rosji, dzięki czemu - jak się spodziewano - uda się uzyskać poparcie cara Mikołaja II dla wspólnych planów. Rozbieżne stanowiska pojawiły się natomiast na tle istotnej dla obu stron kwestii macedońskiej i dotyczyły przyszłości terytoriów zdobytych podczas wojny z Turcją. Projekt serbski zakładał

22 M. Семов, op. cit., s. 45.

23 G. Roloff, op. cit., s. 15.

24 И.Е. Гешов, ор. cit., s. 15-16.

25 B. von Siebert, op. cit., s. 152.

26 DGP, Bd. 33, nr 12040.

27 R. Poincaré, op. cit., s. 63.

28 W. Schröder, England, Europa und der Orient, Stuttgart 1938, s. 71; М. Семов, op. cit., s. 48; Е. Стателова, Р. Попов, В. Танкова, оp. cit., s. 427-428. 
bowiem - zgodnie z ustaleniami podjętymi podczas rozmów z Rizowem - ich podział między koalicjantów. Geszow natomiast, jakkolwiek dopuszczał taką możliwość, stanął na stanowisku, że naczelnym celem sojuszników w wojnie z Turcją powinno być nadanie ziemiom macedońskim szerokiej autonomii. Ostatecznie jednak w toku dyskusji obaj politycy uzgodnili, że Macedonia zostanie podzielona, przy czym Bułgaria otrzyma jej większą część ${ }^{29}$.

Ustalenia te stały się podstawą nowego projektu układu, który przygotowała strona serbska. Projekt ten został przekazany za pośrednictwem posła w Sofii Miroslava Spaljakovicia na początku listopada $1911 \mathrm{roku}^{30}$. Nie został on jednak pozytywnie zaopiniowany przez Bułgarów, co wykazały dyskusje podjęte pod osłoną prac specjalnej bułgarsko-serbskiej komisji ekonomicznej, zajmującej się opracowaniem podstaw gospodarczego zbliżenia między oboma państwami. Wśród spraw spornych najistotniejsze znaczenie miały, omówione i ogólnie uzgodnione już wcześniej kwestie związane z podziałem Macedonii. Dążąc do ostatecznego wyeliminowania idei nadania tej prowincji autonomii, co w ocenie serbskich polityków groziło wchłonięciem jej przez Bułgarię w przyszłości, projekt przewidywał uznanie wszystkich zdobytych w trakcie wojny terytoriów za zdobycz wojenną, która podlegać miała polubownemu podziałowi. W tej kwestii kierować się miano wcześniejszymi ustaleniami, a Macedonia stanowić miała strefę sporną, której podział następowałby przy udziale i pod kontrolą Rosji. Mimo że bułgarscy politycy uprzednio dyskutowali już tę kwestię $\mathrm{i}$ akceptowali takie rozwiązanie, zapis ten spotkał się z ich ostrym sprzeciwem ${ }^{31}$. Ponieważ Bułgarzy nadal lansowali ideę nadania autonomii ziemiom macedońskim, rozmowy uległy zawieszeniu.

Równocześnie jednak strona bułgarska rozpoczęła działania na rzecz nakłonienia Serbów do zmiany stanowiska. Próby takie podjęli Rizow i poseł bułgarski we Francji Dimityr Stanczow podczas pobytu serbskiego monarchy Piotra I i premiera Milovanovicia w Paryżu w drugiej połowie listopada $1911 \mathrm{roku}^{32}$. W trakcie prowadzonych rozmów zwrócili oni uwagę, że podział ziem macedońskich mógłby zostać źle odebrany przez miejscową ludność, a odpowiedzialnością za taki stan rzeczy obarczono by rząd bułgarski. W związku z tym zgodnie z otrzymanymi z Sofii instrukcjami oświadczyli, że zawarcie sojuszu na podstawie przekazanego przez Spaljakovicia projektu nie może być brane pod uwagę ${ }^{33}$. Groźba wycofania się Bułgarii z dalszych pertraktacji odniosła zamierzony skutek. Milovanović zadeklarował gotowość do usunięcia spornych kwestii, a po powrocie do Belgradu zwrócił się do posła rosyjskiego z prośbą o mediacje.

Idea ta była jak najbardziej słuszna. Zakończone niepowodzeniem próby stworzenia bloku bałkańskiego pod przewodnictwem Turcji sprawiły bowiem, że kwestię szybkiego zbliżenia serbsko-bułgarskiego dyplomacja rosyjska zaczęła traktować

\footnotetext{
29 И.Е. Гешов, ор. cit., s. 16-18.

30 Ibidem, s. 19-22.

31 М. Семов, op. cit., s. 52-53.

32 И.Е. Гешов, ор. cit., s. 22-28; Der diplomatische Schriftwechsel Iswolskis 1911-1914, hrsg. F. Stieve, Bd. 1, Berlin 1926, nr 157, 160; Е. Стателова, Р. Попов, В. Танкова, op. cit., s. 430.

33 И.Е. Гешов, ор. cit., s. 26.
} 
priorytetowo. Dlatego też posłowie w państwach bałkańskich otrzymali polecenie otoczenia rozmów kuratelą i czuwania, aby ewentualne rozbieżności zdań nie wpływały na tempo pertraktacji ${ }^{34}$. Jednocześnie mieli oni dbać o to, aby przyszły traktat sojuszniczy nie miał ofensywnego charakteru ${ }^{35}$, co podyktowane było składanymi oficjalnie przez rząd rosyjski zapewnieniami, że nie dopuści do jakichkolwiek prób zmiany istniejącego na Półwyspie Bałkańskim status quo, do czego mogłaby inspirować potencjalnych zainteresowanych trwająca wojna włosko-turecka ${ }^{36}$. Stąd też zapoznanie się ze szczegółami toczących się od dwóch miesięcy rozmów było jak najbardziej pożądane. Wyniki tych działań nie nastrajały jednak optymistycznie, a poważne obawy budziły wyrażane przez obie strony zgodne opinie na temat konieczności szybkiego rozpoczęcia wspólnych działań zbrojnych przeciw Turcji. Ponaglani jednak przez ministra spraw zagranicznych Sergiusza Sazonowa N. Hartwig i A. Niekludow, postanowili ograniczyć naciski w tej kwestii i skupić się na sprawach spornych, które do tej pory uniemożliwiały obu stronom zawarcie porozumienia. Działania te szybko przyniosły spodziewany skutek, ponieważ zarówno Milovanović, jak i Geszow mocno zainteresowani byli pozytywnym zakończeniem rozmów, ale jednocześnie obie strony wyraźnie akcentowały, że punktem wyjścia dalszych konsultacji może być jedynie idea konfrontacji z Turcją i niechętnie odnosiły się do sugestii ${ }^{37}$ dotyczących osłabienia ofensywnego charakteru przyszłego traktatu. O tym istotnym aspekcie rosyjscy dyplomaci, skupieni na mediacjach w kwestii macedońskiej, nie przekazywali jednak informacji do Petersburga.

Na postawę serbskich i bułgarskich polityków istotny wpływ miały także wydarzenia, które rozgrywały się w tym czasie na Półwyspie Bałkańskim. Wprowadzane przez młodoturków reformy spotkały się ze stanowczym oporem nie tylko Albańczyków, ale także chrześcijańskich mieszkańców Macedonii, który wkrótce przerodził się w otwarty bunt. Do jego thumienia władze tureckie wykorzystywały początkowo głównie znane ze swej brutalności paramilitarne oddziały baszybuzuków. Ich działania, kończące się najczęściej grabieżami i mordami ${ }^{38}$, wywoływały powszechną panikę i spowodowały wielką falę migracyjną, która skierowała się do sąsiednich państw. Przekazywane przez uchodźców informacje na temat szalejącego w Macedonii terroru radykalizowały miejscowe społeczności i mobilizowały je do organizowania manifestacji, w trakcie których domagano się podjęcia stanowczych kroków dla przeciwdziałania tureckiemu okrucieństwu. Do szczególnie licznych i częstych demonstracji dochodziło od początku października 1911 roku w Bułgarii ${ }^{39}$, a ich uczest-

34 Международные отношения в эпоху империализма. Документы из архивов иарского и Временного правительств 1878-1917 г2., серия 2: 1900-1913, т. 18, ч. 2, Москва-Ленинград 1938, nr 563. M. Tanty, Rosja..., s. 54-60.

35 W. Schröder, op. cit., s. 74-75; MOE, т. 18, ч. 2, nr 512, 526, т. 19, ч. 1, nr 159; na ten temat: H. Batowski, Podstawy..., s. 112-113; G. Roloff, op. cit., s. 10, J.R. Budziń ski, Polityka zagraniczna Rosji 1907-1914, Toruń 2000, s. 139-140.

36 DGP, Bd. 33, nr 12043, 12038.

37 MOE, т. 18, ч. 2, nr 526; H. Batowski, Podstawy.., s. 112-113.

38 DGP, Bd. 33, nr 12036, 12037, 12043; M. Семов, ор. cit., s. 56.

39 DGP, Bd. 33, nr 12035. 
nicy nie tylko wyrażali solidarność z pobratymcami w Macedonii, ale także otwarcie krytykowali rząd za brak zainteresowania tym problemem ${ }^{40}$. Tymczasem napięcie w Macedonii rosło, a jego kulminacją stały się zamachy bombowe na transporty wojskowe w okolicach Veles i Dojran 3 grudnia oraz na meczet w miejscowości Štip 4 grudnia $1911 \mathrm{roku}^{41}$. W odwecie władze tureckie podburzyły lokalną turecką społeczność, która dokonała masakry swoich chrześcijańskich sąsiadów. W zajściach śmierć poniosło ponad 20 osób a 230 zostało rannych ${ }^{42}$. Wydarzenia te wpłynęły na dalszą radykalizację postaw społecznych, a liczba demonstracji, w trakcie których otwarcie wzywano do podjęcia działań zbrojnych przeciw Turcji, wyraźnie wzro$\mathrm{sła}^{43}$. Drugim istotnym czynnikiem wpływającym na postawę serbskich i bułgarskich polityków były działania władz tureckich, które pod pozorem manewrów rozpoczęły na początku października 1911 roku koncentrację znacznych sił wojskowych w okolicach Adrianopola ${ }^{44}$. Działania te, mimo zapewnień Wysokiej Porty, że nie są skierowane przeciw sąsiednim państwom, poważnie niepokoiły kręgi polityczne i wojskowe w bałkańskich stolicach, zwłaszcza w Sofii ${ }^{45}$. W związku z tym pod koniec grudnia 1911 roku rozmowy serbsko-bułgarskie zostały wznowione.

Podstawą konsultacji prowadzonych przez Spaljakovicia i Geszowa był nowy projekt układu sojuszniczego przygotowany przez stronę serbską. Rozmowy nie przebiegały jednak gładko, a spór po raz kolejny wybuchł na tle kwestii macedońskiej i przebiegu linii podziału tej prowincji ${ }^{46}$. Zacięte dyskusje na ten temat starali się łagodzić uczestniczący w naradach rosyjscy dyplomaci - Niekludow oraz attaché wojskowy w Sofii płk Gieorgij Romanowski ${ }^{47}$. Nie ulega wątpliwości, że to dzięki ich wysiłkom ta tura negocjacji zakończyła się na początku stycznia 1912 roku kompromisowymi ustaleniami ${ }^{48}$. Jakkolwiek strony nadal prezentowały odmienne stanowiska odnośnie do przyszłości ziem macedońskich i ewentualnej linii ich podziału, zgodnie wyraziły gotowość do podpisania układu sojuszniczego w najbliższej przyszłości, a kwestie sporne zdecydowały się rozstrzygnąć w tajnym aneksie, którego treść miała zostać uzgodniona w późniejszym terminie ${ }^{49}$. Mimo tych deklaracji na życzenie strony bułgarskiej, oba dokumenty redagowano jednocześnie, a prace te

40 М. Семов, op. cit., s. 51; Н. Станев, op. cit., s. 199.

${ }^{41}$ Н. Станев, op. cit., s. 201.

42 М. Семов, op. cit., s. 55.

43 Балканската война през погледа на един франиузин, сьст. С. Славова, Ц. Дойнова, София 1977, s. 41; G. Roloff, op. cit., s. 15-16. Liczne demonstracje organizowane były także wiosną 1912 r. DGP, Bd. 33, nr 12045; B. von Siebert, op. cit., s. 522-525, 528, a następnie latem tego roku, zwłaszcza po masakrze chrześcijańskich mieszkańców miejscowości Kočani po zamachu bombowym 1 VIII; Н. Станев, op. cit., s. 205; W. Schröder, op. cit., s. 123; Балканската война..., s. 46-47, 52-53; ÖUA, Bd. 4, nr 3679, 3687, 3706, Der diplomatische Schriftwechsel..., Bd. 2, nr 413; И.Е. Гешов, оp. cit., s. 38.

44 DGP, Bd. 33, nr 12036, 12037.

45 R. Poincaré, op. cit., s. 63; DGP, Bd. 33, nr 12036.

46 MOE, т. 19, ч. 2, nr 354, 370, 371, 374, 388, 406, 448, 452.

47 И.Е. Гешов, ор. cit., s. 28; М. Семов, ор. cit., s. 62. Jednocześnie rząd rosyjski rozpoczął bezpośrednie naciski w Belgradzie; MOE, т. 19, ч. 2, nr 371, 388.

48 MOE, т. 19, ч. 1, nr 338, т. 19, ч. 2, nr 354.

49 И.Е. Гешов, op. cit., s. 28. 
toczyły się w Sofii przez kolejne dwa miesiące. W trakcie konsultacji nadal jednak dochodziło do zaciętych sporów zarówno w kwestii macedońskiej ${ }^{50}$, jak i stosunku koalicjantów do sąsiednich państw, w które wielokrotnie musiała ingerować dyplomacja rosyjska ${ }^{51}$. Mimo tych trudności ostateczna wersja dokumentów ${ }^{52}$ została przekazana do Belgradu na początku 1912 roku, gdzie 11 marca parafował je król Piotr I i premier Milovanovićs ${ }^{53}$. Dwa dni później swoje podpisy złożyli na nich także car Ferdynand I i premier Geszow ${ }^{54}$.

Integralną częścią traktatu sojuszniczego miała być wzmiankowana w nim konwencja wojenna. W tej kwestii także pojawiły się jednak liczne problemy, w których rozwiązywanie także musiała angażować się dyplomacja rosyjska. Mimo nacisków strony serbskiej Bułgarzy odwlekali moment rozpoczęcia rozmów, argumentując to zaplanowanymi wcześniej podróżami cara Ferdynanda I, a następnie jego chorobą ${ }^{55}$. W związku z tym konsultacje szefów Sztabów Generalnych gen. Radomira Putnika i gen. Iwana Ficzewa rozpoczęły się dopiero na początku maja 1912 roku i prowadzone były początkowo w monastyrze Bukovo koło Negotina, a następnie w Warnie. Rozmowy przebiegały jednak w bardzo napiętej atmosferze, a w kilku istotnych kwestiach nie udało się osiągnąć porozumienia do ich zakończenia. Jedną z nich była sprawa wyznaczenia kierunków działania dla sprzymierzonych armii. W trakcie zaciętych dyskusji ${ }^{56}$ uzgodniono ostatecznie, że terenem operacyjnym dla sił bułgarskich będzie dolina Maricy, a dla serbskich dolina Wardaru, przy czym Bułgarzy zobowiązali się do aktywnego wspierania sojusznika na tym teatrze wojennym. Poważnym problemem stało się także wyznaczenie naczelnego dowództwa sprzymierzonych sił. Ponieważ strony nie były w stanie dojść w tej kwestii do porozumienia, pominięto ją w tekście konwencji i wskazano, że poszczególne części sprzymierzonych wojsk znajdować się będą pod ich własną komendą. Efektem takiego stanu rzeczy był fakt, że zapisy podpisanej 12 maja 1912 roku $^{57}$ konwencji miały relatywnie ogólny charakter, co stwarzało możliwości różnej ich interpretacji.

W tym czasie trwały także rozmowy Serbii i Bułgarii z Czarnogórą. Te również nie przebiegały gładko, ale przyczyna problemów była inna niż w przypadku rokowań serbsko-bułgarskich. Czarnogóra nie graniczyła bowiem z newralgicznymi z ich punktu widzenia ziemiami macedońskimi, a swoje roszczenia terytorialne lokowała

50 MOE, т. 19, ч. 2, nr 502, 520, 527, 546, 599.

51 Ibidem, т. 19, ч. 2, nr 502, 511, 527, 528, 599.

52 Teksty dokumentów m.in. ж: И.Е. Гешов, ор. cit., s. 84-88; Dokumente aus russischen Geheimarchiven soweit sie bis zum 1. Juli 1918 eingegangen sindб, Berlin 1919, s. 31-34; MOE, т. 19, ч. 2, nr 625; J. Rubacha, A. Malinows ki, A. Giza, Historia Butgarii 1870-1915. Materiaty źródlowe $z$ komentarzami, t. 1, Warszawa 2006, s. 85-89.

53 MOE, т. 19, ч. 2, nr 599, 613; H. Batowski, Postawy..., s. 115.

54 Ibidem, т. 19, ч. 2, nr 618, 625, 626, 636.

55 Ibidem, т. 19, ч. 2, nr 772, 777.

56 Dokumente aus russischen Geheimarchiven..., s. 289-290.

57 Tekst dokumentu m.in.: И.Е. Гешов, op. cit., s. 88-92; Българска военна история. Подбрани извори и документи, т. 2, София 1984, s. 446-448; Н. Станев, ор. cit., s. 246-248, Dokumente aus russischen..., s. 35-38, MOE, т. 19, ч. 2, nr 888; J. Rubacha, A. Malinowski, A. Giza, op. cit., s. 94-97. 
w północnej Albanii oraz w sandżaku nowobazarskim. Niemniej jednak prowojenne nastawienie tego niewielkiego państwa, a zwłaszcza utrzymujące się od długiego czasu napięcie w jego stosunkach z Turcją, które stale groziło wybuchem konfliktu zbrojnego, budziło zarówno wśród bułgarskich, jak i serbskich polityków obawy, że zostaną uwikłani w konflikt w nieodpowiednim dla nich momencie. Nieporozumienia ujawniały się także w innych obszarach. Jakkolwiek Czarnogóra wsparła Serbię w konflikcie z Austro-Węgrami w 1908 roku i zawarła z nią układ wojskowy ${ }^{58}$, jej wycofanie się kilka miesięcy później z kryzysu bośniackiego ${ }^{59} \mathrm{~W}$ zamian za płynące z Wiednia obietnice zniesienia ograniczeń dotyczących czarnogórskiego wybrzeża i swobody żeglugi ${ }^{60}$ uznano w Belgradzie za zdradę serbskich interesów. Równie nieprzychylnie Serbia odniosła się, głównie ze względów ambicjonalnych, do proklamowania przez Mikołaja I w sierpniu 1910 roku Królestwa Czarnogóry. Poza tym zarówno Serbowie, jak i Bułgarzy, znający potencjał militarny Czarnogóry nie postrzegali jej jako ewentualnego koalicjanta. Dlatego też podejmowane przez Mikołaja I latem i jesienią 1911 roku próby pozyskania Bułgarii i Serbii do współpracy w przypadku konfliktu z Turcją zostały odrzucone, a oba państwa, zgodnie z sugestiami wrogiej takim inicjatywom dyplomacji rosyjskiej, doradzały mu porzucenie ofensywnych planów. W związku z tym w listopadzie 1911 roku Czarnogóra zaproponowała zawarcie sojuszu Austro-Węgrom. Zgodnie z przewidywaniami inicjatywa ta nie spotkała się w Wiedniu z zainteresowaniem, co nie przeszkodziło jednak Mikołajowi I rozpocząć pertraktacji na temat uzyskania od monarchii habsburskiej wsparcia finansowego ${ }^{61}$, które zamierzał przeznaczyć na wspieranie albańskich powstańców. Prowadzone w tym obszarze na przełomie 1911 i 1912 roku negocjacje ${ }^{62}$ spowodowały jednak natychmiastową reakcję Rosji, która zażądała od Czarnogóry natychmiastowego ich przerwania ${ }^{63}$. Mimo że Mikołaj I spełnił ten nakaz ${ }^{64}$, dyplomacja rosyjska nadal odrzucała możliwość ewentualnego włączenia się Czarnogóry w rozmowy bułgarsko-serbskie ${ }^{65}$, ale po uregulowaniu wzajemnych stosunków w połowie marca 1912 roku, nie przykładała do tej kwestii większej uwagi, tym bardziej że strona czarnogórska zobowiązała się utrzymywać poprawne kontakty z Turcją i nie wspierać ruchu powstańczego w Albanii.

Zmiana nastawienia dyplomacji rosyjskiej nie wpłynęła jednak w znaczący sposób na postawę Serbii, a utrzymujące się nadal chłodne stosunki serbsko-czarnogórskie ${ }^{66}$ zadecydowały o tym, że układ sojuszniczy i konwencję wojenną strony podpisały dopiero 29 września 1912 roku $^{67}$. Niewiele wcześniej zakończyły się

58 ÖUA, Bd. 1, nr 348, 380, 541, O. Bicke1, op. cit., s. 21-22, B. von Siebert, op. cit., Bd. 1, nr 19.

59 ÖUA, Bd. 2, nr 1478.

${ }^{60}$ Ibidem, Bd. 2, nr 1114, 1115, 1137, 1166.

${ }_{61} \mathrm{MOE}$, т. 19, ч. 2, nr 425.

62 Ibidem, т. 19, ч. 2, nr 477, 485.

63 Ibidem, т. 19, ч. 2, nr 500, 521, 687; O. Bickel, op. cit., s. 132.

64 Ibidem, т. 19, ч. 2, cz. 2, nr 651; O. Bicke1, op. cit., s. 132.

65 Ibidem, т. 19, ч. 2, nr 878; B. von Siebert, op. cit., s. 522-525; G. Roloff, op. cit., s. 19.

66 B. von Siebert, op. cit., s. 576; MOE, т. 19, ч. 2, nr 687.

67 H. Batowski, Podstawy..., s. 118. 
pertraktacje czarnogórsko-bułgarskie, zainicjowane w drugiej połowie czerwca 1912 roku przez premiera gen. Mitara Martinovicia w trakcie spotkania z Rizowem i przewodniczącym bułgarskiego Zgromadzenia Narodowego Stojanem Danewem w Wiedniu. Podczas przeprowadzonych dyskusji politycy potwierdzili wolę zacieśnienia stosunków ${ }^{68}$, a strona czarnogórska zobowiązała się przygotować projekt układu. Deklarację tę potwierdził osobiście król Mikołaj I 18 lipca podczas rozmowy z posłem bułgarskim w Cetynii, Nedjałko Kołuszewem, a miesiąc później przekazał mu projekt układu sojuszniczego ${ }^{69}$. Dokument ten przewidywał wspólne wystąpienie przeciw Turcji i zajęcie jej europejskich posiadłości, a następnie ich podział z uwzględnieniem interesów innych państw bałkańskich oraz Albańczyków. Gdyby dyskusje na ten temat nie przyniosły rozstrzygnięcia, zakładano wyznaczenie arbitra, którym miał zostać car Rosji lub prezydent Stanów Zjednoczonych ${ }^{70}$. Jednocześnie w dokumencie zawarto klauzulę, w której zakładano pozyskanie do współpracy Serbii i Grecji, co wskazuje, że Bułgarzy nie poinformowali strony czarnogórskiej, że takie porozumienia już wcześniej zawarli. Projekt układu Kołuszew przywiózł do Sofii w połowie sierpnia 1912 roku $^{71}$. Został on pozytywnie zaopiniowany przez rząd bułgarski i zaaprobowany przez radę koronną, która odbyła się 26 sierpnia 1912 roku w carskim pałacyku Carska Bistrica koło miejscowości Czamkoria (obecnie Borowec) $)^{72}$. Ostateczne rozmowy przeprowadził Kołuszew w Cetynii, a strony zawarły porozumie w formie ustnej 28 sierpnia 1912 roku $^{73}$, uzgadniając dodatkowo liczebność sił czarnogórskich w wojnie z Turcją oraz wysokość bułgarskiej pomocy finansowej ${ }^{74}$.

Na tym zakończyło się formowanie bloku w jego „słowiańskiej” części. Trudno jednak nie wspomnieć choćby przebiegu pertraktacji z jeszcze jednym koalicjantem, czyli z Grecją, po pierwsze dlatego, że była ona istotnym elementem porozumienia, które w historiografii określane jest mianem sojuszu bałkańskiego, a po drugie, dlatego że podjęte z tym państwem uzgodnienia lub ewentualnie ich brak w znaczący sposób zaważyły na jego spoistości.

Początkowo enigmatyczne pertraktacje z Grecją na temat ewentualnego zbliżenia prowadziła od 1909 roku tylko Bułgaria ${ }^{75}$, a na dwa miesiące przed wybuchem I wojny bałkańskiej podjęła je Czarnogóra ${ }^{76}$. Jakkolwiek Grecy, podobnie jak Bułgarzy i Serbowie, z niepokojem obserwowali prowadzoną po 1903 roku przez mocarstwa w europejskich posiadłościach Turcji akcję reformatorską, napięte stosunki na tle kwestii macedońskiej skutecznie uniemożliwiały im nawiązanie współpracy.

68 И.Е. Гешов, оp. cit., s. 33.

69 DGP, Bd. 33, nr 12107, 12114.

70 H. Batowski, Podstawy..., s. 116-117.

71 И.Е. Гешов, ор. cit., s. 33; na ten temat: ÖUA, Bd. 4, nr 3727, 3730, 37333745.

72 И.Е. Гешов, op. cit., s. 39.

73 Е. Стателова, Р. Попов, В. Танкова, оp. cit., s. 442-443.

74 А. Тошев, op. cit., s. 361; ÖUA, Bd. 4, nr 3906.

75 B. von Siebert, op. cit., s. 148-149; Н. Станев, op. cit., s. 202.

76 Zakończyły się one w sierpniu 1912 r. zawarciem ustnego porozumienia; H. Batowski, Podstawy..., s. 117. 
Sytuacja uległa niewielkiej zmianie w 1910 roku w związku z nasileniem się działań osmanizacyjnych w Macedonii oraz rozszerzeniem się ruchu powstańczego w Albanii ${ }^{77}$. Stąd też grecki premier Elefterios Venizelos podjął latem tego roku próby pozyskania informacji na temat stosunku Belgradu i Sofii do ewentualnego nawiązania współpracy i podjęcia wspólnych działań na rzecz poprawy położenia ludności chrześcijańskiej zamieszkującej w granicach państwa tureckiego. Ponieważ działania te nie spotkały się z zainteresowaniem w Serbii ${ }^{78}$, jesienią 1910 roku Grecy rozpoczęli rozmowy z Bułgarami. Konsultacje nie zakończyły się jednak żadnymi przełomowymi ustaleniami i ostatecznie po kilku tygodniach zostały zawieszone. Próby ich wznowienia przedsięwzięła strona grecka w styczniu, a następnie wiosną 1911 roku ale wysiłki te również okazały się bezowocne ${ }^{79}$. Dopiero zaangażowanie się w tę kwestię dyplomacji brytyjskiej, która za pośrednictwem korespondenta i dziennikarza londyńskiego „Times'a” Jamesa Davida Bourchiera wsparła ideę zbliżenia między oboma państwami, przyniosło pozytywne rezultaty ${ }^{80}$. Rozmowy zostały wznowione w maju 1911 roku i przybrały relatywnie szeroki wymiar. W ich trakcie strony potwierdziły chęć współpracy na rzecz poprawy położenia ludności chrześcijańskiej w europejskich posiadłościach Turcji, a nawet wyraziły gotowość podpisania traktatu sojuszniczego, ale konsekwentne unikanie przez Greków określenia aspiracji terytorialnych, czego domagała się strona bułgarska ${ }^{81}$, szybko doprowadziło do impasu i konsultacje po raz kolejny przerwano ${ }^{82}$. Podjęto je raz jeszcze pod koniec kwietnia 1912 roku, a podstawą dyskusji stał się przygotowany w Atenach i zaprezentowany przez greckiego posła w Sofii Dimitriosa Panasa projekt traktatu sojuszniczego ${ }^{83}$. Nadal nie precyzował on jednak greckich oczekiwań terytorialnych, co skłoniło Bułgarów, mimo istniejącego już układu z Serbią, do wysunięcia idei podjęcia wspólnej walki o nadanie szerokiej autonomii Macedonii, Tracji i Albanii ${ }^{84}$. Zgodnie z przewidywaniami propozycja ta została odrzucona, a strony nie podejmowały jej w dalszych dyskusjach, nieoficjalnie przyjmując, że nabytki terytorialne Grecji obejmować będą tereny zajęte przez grecką armię w trakcie działań wojennych. Temu zapewne należy zawdzięczać, że po miesięcznych negocjacjach, 29 maja 1912 roku, oba państwa

77 Istotne znaczenie miało także zaostrzanie się stosunków grecko-tureckich na tle kwestii kreteńskiej.

78 Składane przez Grecję propozycje rozpoczęcia rozmów były konsekwentnie odrzucane przez Serbię także w okresie późniejszym i do wybuchu I wojny bałkańskiej strony nie zawarły układu sojuszniczego; Балканската война..., s. 22.

79 Znacząco wpłynęły one jednak na ocieplenie stosunków między Patriarchatem Konstantynopolitańskim a Egzarchatem Bułgarskim, dzięki czemu oba kościoły zgodnie broniły praw chrześcijan na ziemiach macedońskich. N. Stanew, op. cit., s. 202.

80 А. Тошев, op. cit., s. 301 і n.; И.Е. Гешов, op. cit., s. 30.

81 М. Семов, оp. cit., s. 72; na ten temat: MOЕ, т. 19, ч. 2, nr 712; И.Е. Гешов, ор. cit., s. 30-31.

82 И.Е. Гешов, оp. cit., s. 31.

83 МОЕ, т. 19, ч. 2, nr 712, 716; И.Е. Гешов, ор. cit., s. 31; Е. Стателова, Р. Попов, В. Танкова, op. cit., s. 436.

84 И.Е. Гешов, op. cit., s. 31. 
podpisały układ sojuszniczy, który na początku października uzupełniono konwencją wojenną ${ }^{85}$.

Zawarte w 1912 roku układy i porozumienia nie tworzyły jednolitego bloku, mimo że państwa bałkańskie zapowiadały jego powołanie, a kwestia ta wielokrotnie pojawiała się w trakcie prowadzonych dyskusji ${ }^{86}$. Tym samym stworzony blok opierał się wyłącznie na dwustronnych umowach, których wspólnym elementem było możliwie jak najszybsze rozpoczęcie konfrontacji z Turcją. Mimo to sojusz bałkański spełnił pokładane w nim oczekiwania. Jego członkom w trakcie prowadzonych na przełomie roku 1912 i 1913 działań wojennych przeciw Wysokiej Porcie udało się nie tylko rozbić jej siły na Bałkanach, ale także pozbawić ją niemal wszystkich europejskich posiadłości. Mogło się zatem wydawać, że koalicjanci uzyskali możliwość zgodnego ułożenia nowych stosunków w regionie. Niestety błędy popełnione przez bałkańskich polityków i dyplomatów już na etapie formowania sojuszu, mocno zaważyły na jego spoistości. Wśród nich najistotniejsze znaczenie miał niewątpliwie fakt, że, kierując się swoimi partykularnymi interesami, strony składały podczas negocjacji deklaracje, które znacząco różniły się od traktatowych klauzul lub w ogóle nie zostały w nich zawarte, a dodatkowo zatajały przed partnerami istnienie już zawartych porozumień lub prowadzone $\mathrm{z}$ innymi potencjalnymi koalicjantami rozmowy, co świadczyło o dużej podejrzliwości i całkowitym braku zaufania. Jednocześnie bagatelizowały one rozgrywające się na Bałkanach wydarzenia, ignorowały zarówno opinie całego „koncertu europejskiego”, jak i stanowiska poszczególnych wielkich mocarstw, pomijały nastawienie krajów sąsiednich do podejmowanych przez nie działań, a także z niezwykłą wręcz nonszalancją podchodziły do roszczeń innych narodów bałkańskich, które w tym czasie podjęły próby realizacji swych celów narodowych. Stąd też trudno powstrzymać się przed konstatacją, że sojusz bałkański już w momencie powstania skazany był na rozpad, a wewnętrzne spory oraz wzajemne oskarżenia i pretensje doprowadziły ostatecznie do wybuchu konfliktu zbrojnego między koalicjantami. Warto także podkreślić, że sojusz ten mógł odegrać doniosłą rolę w zacieśnieniu kontaktów i budowie trwałych podstaw wielopłaszczyznowej współpracy między narodami słowiańskimi w tej części Europy, a tym samym stać się zwieńczeniem wysiłków podejmowanych w tym obszarze na przestrzeni kilkudziesięciu wcześniejszych lat. Tak się jednak nie stało, co niewątpliwie z jednej strony było efektem wspomnianych wyżej wzajemnych uprzedzeń, a z drugiej strony zupełnej niefrasobliwości Rosji, która mimo że w tamtym czasie uznawana była za orędownika jedności słowiańskiej, nie była w stanie tej roli podołać. Stąd też II wojna bałkańska, a zwłaszcza postanowienia kończącego ją pokoju bukareszteńskiego wykopały głęboką przepaść między państwami bałkańskimi, także tymi słowiańskimi, co nie tylko stawiało je później po różnych stronach barykady w trakcie przełomowych wydarzeń dziejowych, jakimi były I i II wojna światowa, ale także współcześnie implikują chłodne stosunki dwustronne.

85 Teksty dokumentów m.in. w: И.Е. Гешов, ор. cit., s. 96-98, 99-101; Българска военна..., s. 449-450, 473-475; A. Тошев, оp. cit., s. 432, 434-436; J. Rubacha, A. Malinowski, A. Giza, op. cit., s. 100-102, 105-110.

86 A. Krzyżanowski, op. cit., s. 72. 


\section{BIBLIOGRAFIA}

Bickel O., Russland und die Entstehung des Balkanbundes 1912. Ein Beitrag zur Vorgrschichte des Weltkrieges. Dargestellt vorwiegend auf Grund des amtlichen Aktenmaterials, Königsberg-Berlin 1933.

Batowski H., Państwa bałkańskie 1800-1923. Zarys historii dyplomatycznej i rozwoju terytorialnego, Kraków 1938.

Budziński J.R., Polityka zagraniczna Rosji 1907-1914, Torun 2000.

Der diplomatische Schriftwechsel Iswolskis 1911-1914, hrsg. F. Stieve, Bd. 1-3, Berlin 1926.

Die große Politik der europäischen Kabinette, 1871-1914. Sammlung der diplomatischen Akten des Auswärtigen Amtes, hrsg. J. Lepsius, A. Mendelssohn-Bartholdy, F. Thimme, Bd. 24, 27, 33, Berlin 1922-1927.

Dokumente aus russischen Geheimarchiven soweit sie bis zum 1. Juli 1918 eingegangen sind, Berlin 1919.

Fraser I.F., Pictures from the Balkan, London 1906.

Krzyżanowski A., Wojna bałkańska w roku 1912/13, Kraków 1913.

Miecznik A., Macedonja i Macedończycy, Warszawa 1904.

Österreich-Ungarns Aussenpolitik von bosnischen Krise 1908 bis zum Kriegsausbruch 1914. Diplomatische Aktenstücke des Österreich-Ungarischen Ministeriums des Äusseren, ausg. L. Bittner, A.F. Pribram, H. Srbik, H. Übersberger, Bd. 2, Wien-Leipzig 1930.

Poincaré R., Geneza wojny światowej. Sześć odczytów w Paryżu w 1921 r., Kraków 1921.

Roloff G., Die Entstehung des Balkanbundes von 1912, Giessen 1922.

Rubacha J., Malinowski A., Giza A., Historia Butgarii 1870-1915. Materiały źródłowe z komentarzami, t. 1, Warszawa 2006.

Schröder W., England, Europa und der Orient, Stuttgart 1938.

Siebert B. von, Diplomatische Aktenstücke zur Geschichte der Ententepolitik der Vorkriegsjahre, Berlin 1921.

Tanty M., Konflikty batkańskie w latach 1878-1918, Warszawa 1968.

Tanty M., Rosja wobec wojen batkańskich 1912-1913, Warszawa 1970.

Wituch T., Tureckie przemiany. Dzieje Turcji 1878-1913, Warszawa 1980.

Балканската война през погледа на един франиузин, съст. С. Славова, Ц. Дойнова, София 1977.

Българска военна история. Подбрани извори и документи, т. 2, София 1984.

Гешов И.Е., Балканский союз. Воспоминания и документы, Петроград 1915.

Международные отношения в эпоху империализма. Документы из архивов ияарского и Временного правительств 1878-1917 г2., серия 2: 1900-1913, т. 18-19, МоскваЛенинград 1938-1940.

Семов М., Победителят проси мир. Балканските войни 1912-1913, София 1995.

Станев Н., История на нова България 1878-1928, София 1929.

Стателова Е., Попов Р., Танкова В., История на българската дипломация 1879-1913 г., София 1994.

Тошев А., Балканските войни, т. 1, София 1929. 